\title{
Dermoid cyst with bone defect in the frontal zygomatic process. A case report
}

\section{Quiste dermoide con defecto óseo en apófisis cigomática del frontal. Reporte de un caso}

\author{
Juliana M. Morales-Avalos ${ }^{1 *}$, Adolfo J. Torres-Moreno ${ }^{1}$, Jesus A. Cortez-Hernandez ${ }^{2}$ and \\ Hiram J. Arce-Sanchez ${ }^{3}$
}

1Ophthalmology Department, Hospital General de Culiacán «Dr. Bernardo J. Gastelum»; ${ }^{2}$ Pathology Department, Women's Hospital SSA; ${ }^{3}$ Radiology Department, Hospital General de Culiacán «Dr. Bernardo J. Gastelum». Culiacán Rosales, Sinaloa, Mexico

\begin{abstract}
A 23 old female, with a mass in the right zigomaticofrontal region beginning from the childhood. Imaging tests show a cyst on the frontal zigomatic process with a total thickness bone defect under the cyst. Surgical resection was performed. The histopathologic examination resulted in dermoid cyst. The monitoring has been satisfactory. We present this case due to the unusual bone defect because usually the orbital dermoid cyst is located on the frontozygomatic suture.
\end{abstract}

Key words: Orbital dermoid cyst. Eyelid crease approach. Unusual location. Bone defect. Clinical case.

\section{Resumen}

Paciente mujer de 23 años, que presenta aumento de volumen en la región frontocigomática derecha, detectada desde la infancia, se realizan estudios de tomografía axial computarizada y topografía helicoidal multiforme, identificando una lesión quística sobre la apófisis cigomática del frontal, con un orificio de espesor completo del cual emergía la lesión. Se sometió a resección quirúrgica, confirmando por patología el diagnóstico de quiste dermoide; la evolución ha sido satisfactoria. Se presenta el presente caso debido a la rareza del defecto óseo acompañante, dado que generalmente se asocia a una localización sobre la sutura frontocigomática.

Palabras clave: Quiste dermoide orbitario. Abordaje en pliegue palpebral. Localización inusual. Defecto óseo. Caso clínico.

\section{Correspondence:}

*Juliana M. Morales-Avalos

E-mail: marzzela@ hotmail.com
Available online: 01-11-2018 RevMex Oftalmol (Eng).2018;92(6):270-273 www.rmo.com.mx 


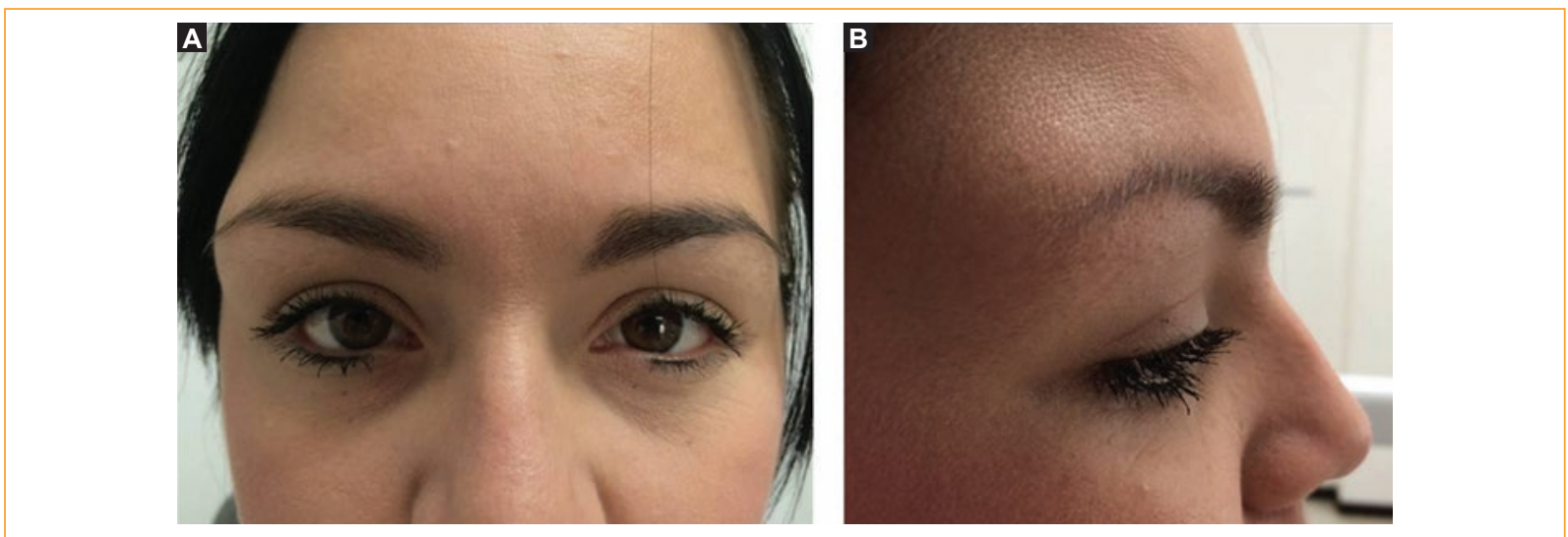

Figure 1. A: Front view. B: Right lateral view.
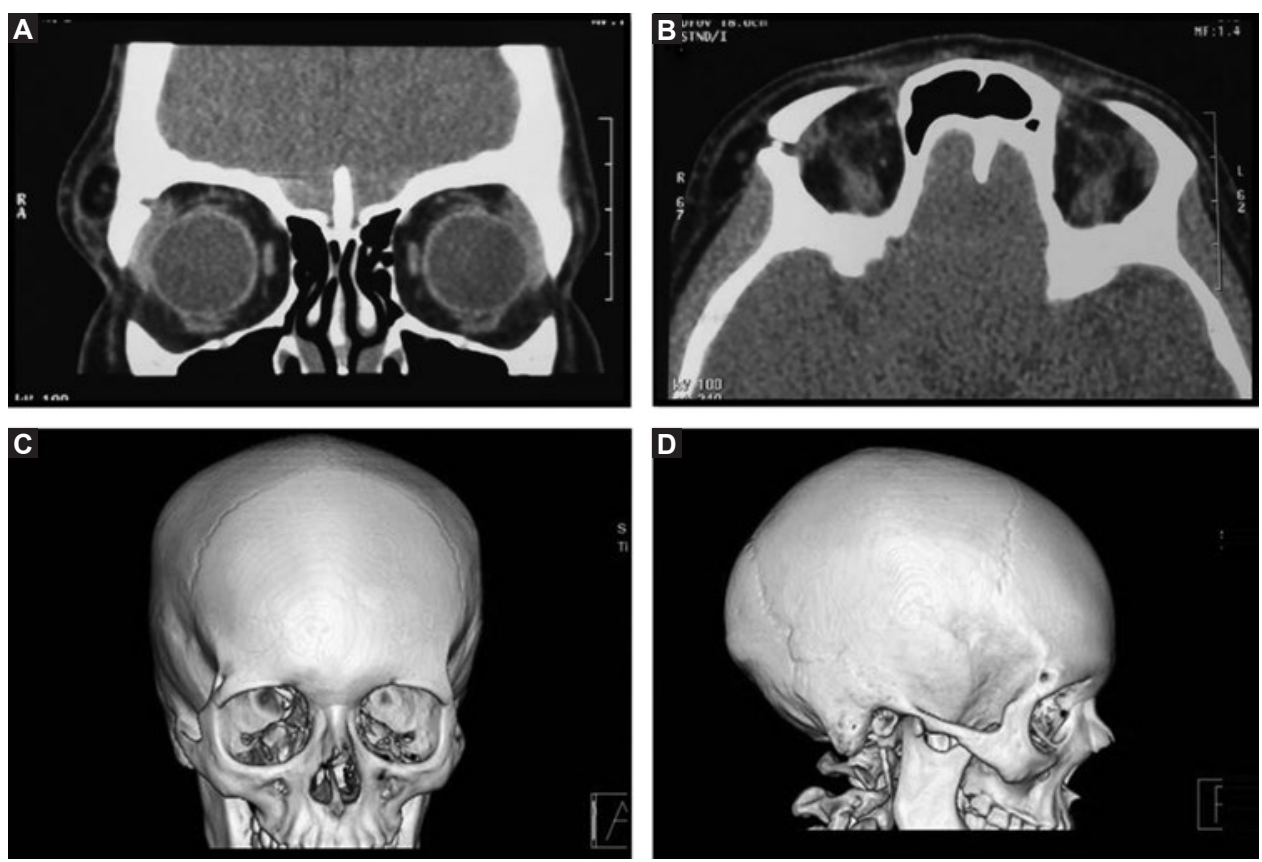

Figure 2. A-D: Coronal axial tomography, axial tomography (orbital axial cut). Helicoidal topography, front view and helicoidal topography, right lateral view.

\section{Introduction}

Dermoids are classified within the group of choristomas, which are congenital lesions originated from aberrant ectodermal tissue ${ }^{1,2}$. They usually arise during embryonic closure between two lines of cranial sutures that trap dermal and subdermal tissue forming a cyst ${ }^{3}$. Fifty percent of skull dermoids are located in the orbit ${ }^{4,5}$. They have no predilection for race or gender ${ }^{6}$. The clinical presentation is a painless orbital mass with slow growth; deep orbital locations can cause diplopia and proptosis ${ }^{7}$. The most common locations in order of frequency are superior temporal and superior nasal ${ }^{8-10}$. Spontaneous or traumatic rupture of the cyst can occur, with an intense inflammatory reaction that can mimic an orbital cellulitis ${ }^{11-13}$.

\section{Case presentation}

A 23-year-old woman attended our ophthalmology service referring increased volume in the right zygomaticofrontal region, identified since childhood, with progressive, painless growth that did not cause any other symptoms (Figs. 1A and B). Biomicroscopy was normal; 


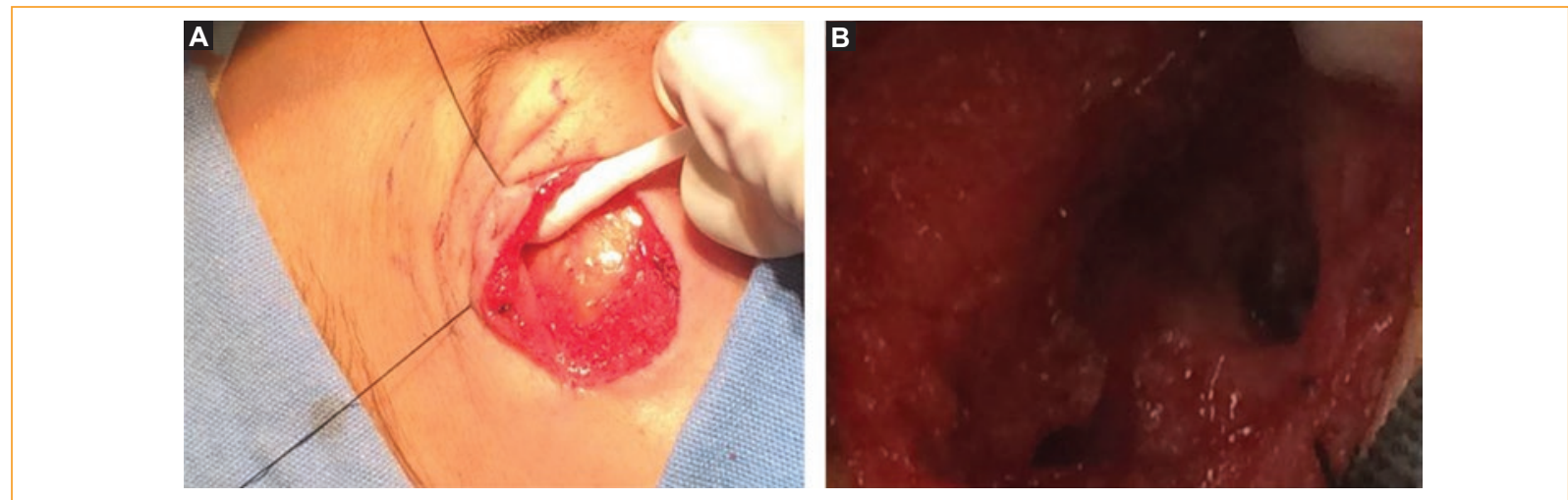

Figure 3. A, B: Dissection of dermoid cyst via upper blepharoplasty, frontal bone defect.

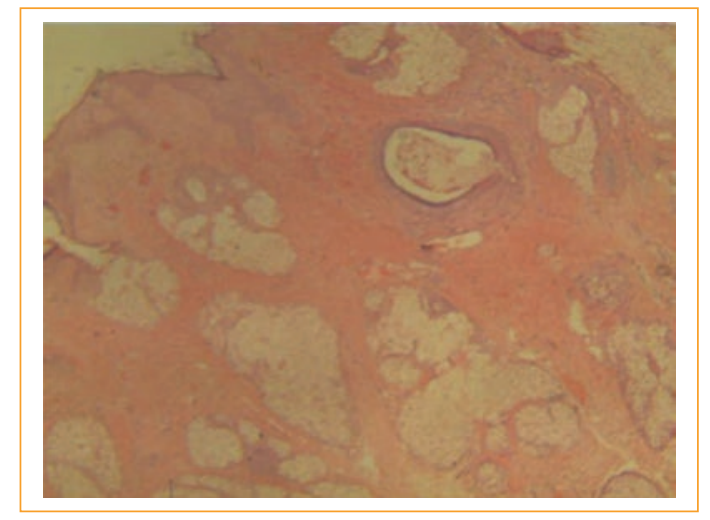

Figure 4. Panoramic photomicrograph of the cystic lesion covered by a keratinized squamous epithelium. Hematoxylin and eosin stain.

we identified a mass in the lateral wall of the right orbit, with defined edges, painless on palpation, fixed to deep planes, with a firm consistency of $2 \times 2 \mathrm{~cm}$. A computerized axial tomography (CT) of the orbits and multiform helicoidal topography showed a hypodense mass with a hyperdense central zone in the lateral wall of the right orbit, adjacent to the temporal muscle towards its posterior margin. The lesion measured $23 \mathrm{~mm}$ in vertical length, $17 \mathrm{~mm}$ in horizontal length and $10 \mathrm{~mm}$ in thickness, and did not enhance with contrast medium administration. The CT also showed the full-thickness bone defect of the zygomatic process in the right frontal bone to which the cystic lesion was attached (Figs. 2 A, B, C and D).

Surgical exeresis was performed by upper blepharoplasty, with dissection and identification of the lesion. After complete resection, the 3-mm bone defect was observed, covered with periosteum in its posterior side.
Then, wound closure was performed by planes (Figs. 3A and B). Histopathological study confirmed the diagnosis of orbital dermoid cyst (Fig. 4). The patient has an adequate evolution 8 months after surgery.

\section{Discussion}

Most cases of lateral orbital wall dermoids are associated with the zygomaticofrontal suture ${ }^{1}$, however; this case was associated with a more superior location in the zygomatic apophysis of the frontal bone, conditioning the presence of an underlying full-thickness bone defect.

\section{Conclusion}

It is important to identify orbital lesions, make an adequate anamnesis of the condition and use the available paraclinical resources to identify the nature of the lesions, and offer the appropriate treatment. This type of choristomes is common in our work center; we received this case with an unusual bone path that generated controversy because at first we thought the bone defect was caused by an erosive process; however, it comprises the full thickness of the frontal bone, suggesting an entrapment of ectodermal tissues during embryonic development.

\section{Ethical disclosures}

Protection of human and animal subjects. The authors declare that no experiments were performed on humans or animals for this study.

Confidentiality of data. The authors declare that no patient data appear in this article. 
J.M. Morales-Avalos, et al.: Dermoid cyst with bone defect in the frontal zygomatic process.

Right to privacy and informed consent. The authors declare that no patient data appear in this article.

\section{Funding}

The authors received no specific funding for this work.

\section{Conflicts of interest}

The authors declare no conflict of interest.

\section{References}

1. Perry JD, Tuthill R. Simultaneous ipsilateral temporal fossa andorbital dermoid cysts. Am J Ophthalmol. 2003;135:413-5.

2. Vega RA, Hidlay DT, Tye GW, Fuller CE, Rhodes JL. Intradiploicdermoid cyst of the lateral frontotemporal skull: case reportand review of the literature. Pediatr Neurosurg. 2013;49:232-5.
3. Sherman RP, Rootman J, Lapointe JS. Orbital dermoids: Clinical presentation and management. Br J Ophthalmol. 1984;68:642-52.

4. Golden BA, Jaskolka MS, Ruiz RL. Craniofacial and orbitaldermoids in children. Oral Maxillofac Surg Clin North Am.2012;24:417-25.

5. Ruszkowski A, Caouette-Laberge L, Bortoluzzi P, Egerszegi EP Superior eyelid incision: An alternative approach for frontozy-gomatic dermoid cyst excision. Ann Plast Surg. 2000;44:591-4.

6. Kersten RC. The eyelid crease approach to superficiallateral dermoid cysts. J Pediatr Ophthalmol Strabismus.1988;25:48-51.

7. Nelson KE, Mishra A, Duncan C. Upper blepharoplastyapproach to frontozygomatic dermoid cysts. J Craniofac Surg. 2011;22:e41-4.

8. Ortube MC, Dipple K, Setoguchi Y, Kawamoto HK Jr, Demer JL. Ocular manifestations of oblique facial clefts. J Craniofac Surg. 2010;21:1630-1.

9. Nevrekar D, Abdu E, Selden NR. Craniectomy for a bilobed der-moid cyst in the temporal fossa and greater wing of the sphenoidbone. Pediatr Neurosurg. 2009;45:46-8.

10. Meyer DR, Lessner AM, Yeatts RP, Linberg JV. Primary temporalfossa dermoid cysts. Characterization and surgical manage-ment. Ophthalmology. 1999;106:342-9.

11. Scolozzi $P$, Lombardi T, Jaques B. Congenital intracranial fronto-temporal dermoid cyst presenting as a cutaneous fistula. Head Neck. 2005:27:429-32.

12. Parag $P$, Prakash PJ, Zachariah N. Temporal dermoid-an unusualpresentation. Pediatr Surg Int. 2001;17:77-9.

13. Sathananthan N, Moseley IF, Rose GE, Wright JE. The frequencyand clinical significance of bone involvement in outer canthusdermoid cysts. Br J Ophthalmol. 1993;77:789-94. 